\title{
Свойства и термодеформационные удк 67.01:120:17 характеристики нанокомпозитов \\ и их вулканизатов на основе сополимера этилена с бутиленом и природными минералами
}

\section{Properties and thermodeformation characteristics of nanocomposites and their vulcanizates based on the copolymer of ethylene-butylene filled with natural minerals}

\section{Н. Т.Кахраманов, И. В. Байрамова,}

Х. В. Аллахвердиева, У. В. Намазлы

Институт полимерных материалов

национальной академии наук Азербайджана

\section{С. С. Песецкий}

Институт механики и металлополимерных систем

Национальной академии наук Республики Беларусь
N. T. Kakhramanov, I. V. Bayramova, Kh. V. Allahverdiyeva, U. V. Namazly Institute of Polymer Materials of the Azerbaijan National Academy of Sciences

\section{S. S. Pesetskiy}

Institute of Mechanics and Metal-Polymer Systems of the Belarus Republic National Academy of Sciences

Поступила в редакцию 26.03.2020, принята к печати 18.11.2020

\section{Абстракт}

Приводятся результаты исследования влияния концентрации природных минералов везувиана и клиноптилолита на термомеханические свойства нанокомпозитов на основе сополимера этилена с бутиленом. Концентрацию везувиана и клиноптилолита варьировали от 0,5 до 20 масс. \%. Установлено, что с увеличением концентрации наполнителя наблюдается повышение температуры размягчения нанокомпозита от 114 до $128^{\circ} \mathrm{C}$. Предлагается механизм процесса формирования межфазной области в минерально-полимерных структурах и ее роли в характере изменения термомеханических кривых. Показано раздельное влияние сшивающих агентов вулканизации - пероксида дикумила и серы на основные физико-механические и теплофизические свойства нанокомпозитов на основе сополимера этилена с бутиленом и природными минералами.

\section{Abstract}

The results of a study of the influence of the concentration of natural minerals vesuvian and clinoptilolite on the thermomechanical properties of nanocomposites based on a copolymer of ethylene with butylene are presented. The concentration of vesuvian and clinoptilolite varied from 0.5 to $20 \mathrm{wt}$. \%. It was found that with increasing filler concentration, an increase in the softening temperature of the nanocomposite from 114 to $128^{\circ} \mathrm{C}$ is observed. A likely mechanism of the formation of the interfacial area in mineral-polymer structures and its role in changes in thermomechanical curves is suggested. A separate effect of the crosslinking vulcanization agents - dicumyl peroxide and sulfur on the main physicomechanical and thermophysical properties of nanocomposites based on a copolymer of ethylenebutylene filled with natural minerals is shown.

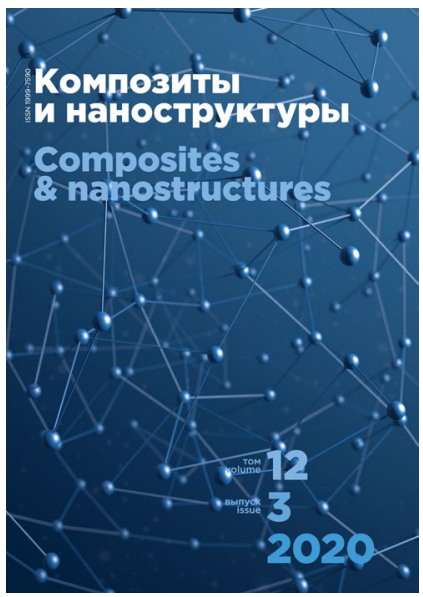

